\title{
DESIGNING THE FUTURE OF WORK WITH SOCIAL ENTERPRISES IN ASIA SEBASTIAN EDWARD GOENADI
}

\section{ABSTRACT}

Social enterprises exist in nearly every sector from consumer goods to healthcare, community energy to creative agencies, restaurants to facilities management. Well known examples include The Big Issue, Divine Chocolate and the Eden Project but there are over 100,000 social enterprises throughout the country contributing $£ 60$ billion to the economy and employing two million people. Social enterprises are businesses, so they must generate the majority (more than $50 \%$ ) of their income through trade. We recognize however, that many start-up businesses need funding to get off the ground and turn to readily available sources. With this in mind we usually expect that within two years of operating, genuine social enterprises generate more than $50 \%$ of their income through their own trading activities.

Although profits are not the primary motivation behind a social enterprise, revenue still plays an essential role in the sustainability of the venture. In fact, sustainable revenue differentiates a social enterprise from a traditional charity that relies on outside funding in the form of donations or grants to achieve its social mission. This does not mean that social enterprises cannot be highly profitable, it simply means that when they are, their priority is the reinvestment of profits into their social mission rather than payouts to shareholders.

In designing the future of work, we need to know the challenges and obstacles that we must face in order for us to design the future itself. Because nowadays business uses technology and technology can be disruptive to the old business systems. It can wreck the old system apart and set a new system based on the up to date technology on top of the old one. Those business in today's world uses Artificial Intelligence (AI) and robotics to do the routine work of humans inside the business and companies. There are 4 stages in technology disruption that you also need to know about.

There are also alternative to the future of work in Asia, which is this social enterprises which gives back to lots of community and the people itself. Because many countries in Asia still have lots of people who do not have homes and healthy environment where they live. So with lots of this social enterprises built in Asia in can decrease the number of unemployed people and increasing the health environment a little bit better because when social enterprises profits, the community or the society profits. 
A social enterprise is a commercial organization that has specific social objectives that serve its primary purpose. Social enterprises seek to maximize profits while maximizing benefits to society and the environment. Their profits are principally used to fund social programs. There are few types of social enterprises in Indonesia, such as

1. Entrepreneurial NPO, emerged from non-profit organizations with a strong philanthropy tradition. Adapted from Defourny and Nyssens (2016), who argue that small and medium-sized enterprises (SMEs) can be motivated by a mission balancing social and economic aspects. In the Indonesian context, SMEs play a pivotal role in terms of number of business units and job creation.

2. Social cooperative (SC) model, which is the result from a move of mutual interest organizations towards a greater concern for the general interest. Adapted from Defourny and Nyssens (2016), who argue that social enterprises of this type result from the evolution of mutual interest associations - which can evolve either towards the entrepreneurial NPO model or the SC model. In the Indonesian context, social enterprises in this group have emerged from societal organizations, including religious group and professional organizations.

3. Community development enterprise (CDE) model, adapted from Defourny and Kim (2011), who argue that this SE model focuses on local development in specific areas. In Indonesia, social enterprises of this type have been emerging following the abovementioned community-based development program PNPM Mandiri, in the 20072015 period. These SEs, launched thanks to initial financial resources provided by the PNPM Mandiri Project, focus on local economic development in rural and urban areas. They foster forms of community-based ownership.

4. Social business (SB) model, Social enterprises belonging to this group emerged with a strong market orientation. This model was adapted from Defourny and Kim (2011), who indicate that this SE model emerges as a result of governments encouraging partnerships between private companies and NPOs, which in turn results in the setting up of new social ventures. In Indonesia, this type of social enterprise operates under the legal form of companies or for-profit organizations to gain credibility with their business partners. SE belonging to this model can be franchised entities of social enterprises from abroad and have a strong orientation toward the international market; examples include The Body Shop Indonesia and The Javara.

On the surface, many social enterprises look, feel, and even operate like traditional businesses. But looking more deeply, one discovers that the defining characteristics of the social enterprise: mission is at the center of business, with income generation playing an important role from The Center for Community Enterprises. An equally noble goal of social enterprise (aside from generating revenues to pursue a mission) is the training and/or employment of people who are typically excluded from the mainstream economy, thus creating capacity and self-sufficiency for individuals, and impacting their communities and lessening reliance on the social safety net. This element alone can denote a social enterprise. Social enterprises create employment and reinvest 
their profits bank into their business or the local community by selling goods and services in the open market. This strategy allows them to tackle social problems, improve people's life chances, provide training and employment opportunities for those furthest from the market, support communities and help their environment. They're creating jobs and opportunities for those most marginalised from the workforce, transforming the communities they work in and making the Sustainable Development Goals a reality. It's business for good and when they profit, society profits.

Community development is a process by which local communities provide the goods and services necessary to achieve their own desired standard living. In Indonesia the community development program gained support from communities with a strong background in various participatory approaches. In Tanjungan village (Indonesia), the women's group launched lending groups to provide access to financial services to poor families. Since then, the social enterprises has further expanded to the tourism business. But in Taiwan, there are some difficulties faced by the community development board of directors, board of supervisors, and members in terms of exercising their accountability. Also, the massive amount of required official paperwork linked to government subsidies goes beyond the ability and capability of the board directors and board supervisors. And then, there are some community development associations have real autonomy in terms of work plans and employment.

Another distinction about the community development between Indonesia and Taiwan is in Tanjungan village gained support from various local organizations, including a lending group, a farmers' group, a women's group and religious leaders. The villagers also quite familiar with the community development program, since the government had launched a family welfare program (PKK) in the previous decades. The action plan in Taiwan used to construct resource network under the GCDA model, the members of the community took part in the decision regarding the needs that should be given the priority. In the case of Indonesia, the planning process for the community development program required an agreement letter from the local community. 
Article: Designing the Future of Work

No one knows what is about to happen in the future, especially about technology (artificial intelligence, robotics, and also big data are also changing the fundamental nature of the work we do. Because technology can turn into good and bad things, we need to understand first about it and how will it impact on our future work. Business nowadays is also using more and more the easiness of using technologies, such as E - Business or online business which requires a good and up to date technology to do it. As we are learning and understanding on how will it impact on our business, we could make our way to the future through the disruption of technology.

A disruptive technology is one that displaces an established technology and shakes up the industry or a ground - breaking product that creates a completely new industry of its own. History records that technological disruption is inevitable. For me, here in Asia where the technology is still behind if compared to the western countries, it is crucial to know and understand well about these technology that might help us in the future and understand the disruption to see if this disruption can be solved like any other matter that happen before and take precaution for it. There are four stages of disruption:

1. Disruption of Incumbent

The incumbent's reactions to potential technology disruptions are practically cliché. And the primary reaction is to essentially ignore the product or technology.

2. Rapid Linear Evolution

Once an innovative product or technology begins rapid adoption, the focus becomes "filling out" the product. In this phase, the product creators are still disruptors, innovating along the trajectory they set for themselves, with a strong focus on early-adopter customers, themselves disruptors. The disruptors are following their vision. The incumbents continue along their existing and successful trajectory, unknowingly sealing their fate.

3. Appealing Convergence

As the market redefinition proceeds, the category of a new product starts to undergo a subtle redefinition. No longer is it enough to do new things well; the market begins to call for the replacement of the incumbent technology with the new technology. In this phase, the entire market begins to "wake up" to the capabilities of the new product.

4. Complete Reimagination

The last stage of technology disruption is when a category or technology is reimagined from the ground up. While one can consider this just another disruption, it is a unique stage in this taxonomy because of the responses from both the legacy incumbent and the disruptor. 
This class also teach us about how important it is in the workplace of the future where automation and artificial intelligence may begin to take over more routine tasks. Also the strategies for understanding how to develop effective human - machine relationships. Because we can rapidly feed vast amounts of data to them, machines appear to be learning and mimicking us, but in fact they are still at the mercy of the algorithms we provide. The way for us to think of modern artificial intelligence is to understand two concepts:

1. Computers can ingest millions of data points per second and make instant calculations and predictions based on this data set.

2. Very specific rules can be written to help a computer system understand what to do once a calculation is made.

If you invest in and take advantage of what AI can do for your business, good things are likely to happen to you. And if you don't, you'll still discover that the revolution is real - but you might not be on the right side of history. That is why we need to understand about the changes in technologies especially in Asia because there are many challenges and threats all around us and if you understand it well, you can devise a strategy to ensure that you are still in control of your own work future. 


\section{References}

Pratono, Pramudija, Sutanti (2019). Social enterprise in Indonesia: Emerging models under transition government, Bidet \& Defourny (ed), Social Enterprise in Asia: Theory, Models, and Practice, London: Routledge

Pratono \& Wong (2019). Social enterprise for rural community development: Lesson from two case studies in Indonesia and Taiwan, Bidet \& Defourny (ed), Social Enterprise in Asia: Theory, Models, and Practice, London: Routledge

BC Centre for Social Enterprise. (n.d.). Social enterprise - Do definitions matter? https://www.centreforsocialenterprise.com/what-is-social-enterprise/

Cadwell, A. (2019). What Is A Social Enterprise? A Simple Definition \& 3 Examples . https://www.thegoodtrade.com/features/what-is-a-social-enterprise

McIntyre, A. P. (2019). Designing the Future of Work. https://www.coursera.org/learn/designing-future-of-work

Rouse, M. (2016). Disruptive Technology.

https://whatis.techtarget.com/definition/disruptive-technology

Sinofsky, S. (2014). The Four Stages of Disruption. https://www.vox.com/2014/1/6/11622000/the-four-stages-of-disruption-2

Social Enterprises UK. (n.d.). What is it all about? https://www.socialenterprise.org.uk/what-is-it-all-about 